\title{
The Usage of Morbid Themes and Imageries in Contemporary Art: A Case Study of "12: A Group Exhibition in Anticipation of the 2012 Apocalypse"
}

\author{
Kanwal Syed \\ Sarena Abdullah, PhD. \\ School of Arts, Universiti Sains Malaysia, \\ Penang, Malaysia
}

Doi:10.5901/mjss.2013.v4n10p128

\begin{abstract}
Death and mortality have not only become a major trend in various forms of visual communication during contemporary times but almost an obsession. These themes of hopelessness, violent imagery and mortality of life have also been a prominent element of contemporary art scene since the arrival of critical post modernism in the 1980's but it was not until the arrival of the 21 st century that these themes took a strong hold. There are many factors that contributed to the contemporaneity's fixation with morbidity and mortality. The absence of religious narratives in the modern society left a void in the lives of many creating a sense of despair. The failure of ideologies like socialism and communism which are replaced by consumer capitalism as an undesirable but only viable path ended the idealistic aspirations of turning the world into a better place collectively for all mankind. But the biggest blow on contemporary art came with the horrific incident of September 11 suicide attacks upon the soil of the United States. In the atmosphere of a world obsessed with the transience of life nothing could be more welcome than the Mayan myth, the end of the world on the eve of 21/12/12. In anticipation of the world coming to an end, an exhibition was arranged by 12 local artists from Penang, Malaysia. Using the exhibition as a case study this article examines the obsession of contemporary art with the mortality and transience of life and floats an apprehensive thought, is the sense of hopelessness and apocalypse on individual or collective level the only message contemporary artists have or is it just a commercial hype, in sync with the same capitalist consumer society it criticizes? Selling what sells nothing more nothing less?
\end{abstract}

\section{Introduction}

Death and mortality have not only become a trend in various forms of visual communication during contemporary times but almost an obsession. Print media, cinema, television even the cyber games for children contain extremely violent and morbid imageries and suggestions. In an article by Victoria J. Grube, an art teacher in a school:

"As an after-school art teacher and student-teacher supervisor, the contact I have with young artists exposes me to the screenager culture. I observe youth freely telling stories and acting out violent scenarios that appropriate the composition, language, and narrative aspects of video game." (Grube, 2012, p. 26)

The American television shows like Dexter, The Walking Dead, Hemlock Grove and various movies that romanticize serial killers, assassins and vampires have become major trends in American media culture. These television shows and movies are watched even at the remotest places on earth via satellite channels, internet and cinema. This tickles down to sub trends in local cinemas and local television shows. On the various news channels every day, we are flooded with footages of violence from around the world containing the latest news about genocides, natural disasters, mass killings and terrorists 'attacks. These violent imageries have almost numbed nations to the level of voyeurs and turned collective or individual miseries on news channels into a mere spectator sport.

The trend of this violent hopelessness and morbid imagery constitutes a prominent element in the contemporary art world as well. The object of this paper is to not only identify the over whelming trends of morbidity in contemporary art but also to suggest an apprehensive thought, where this is leading the current art world? Is hopelessness and morbid obsession with mortality the only message contemporaneity is all about? 


\section{What is Contemporary Art?}

The word contemporary or a newly coined term "contemporaneity" has probably been the most sought after term in art currently, after "postmodernism". Although contemporary follows from the premise of critical postmodernism, it is being considered as a replacement to postmodernity. Contemporaneity is the present; it is the "Now" as has never been before. As Joan Kee explains, "The idea of contemporaneity, a word that has gained increasing currency as a presumptive replacement for post modernity" (Kee, 2011, p. 371). According to Terry Smith, postmodernism is passé' and has served just as a transition between modernism into the contemporary. He explains that we have reached the limits of postmodernist explanation as "the world stands face to face with itself, in all its rich contemporaneity" (Smith, 2009, p. 254). In general, "contemporary" means happening, existing, living, or coming into being during the same period of time. Contemporary art or the term contemporaneity in art falls under the rubric of critical postmodernism. Now, it has become an independent entity that is in sharp contrast to the universalism or formalization mooted by modernism that emphasized the principal of "l'art pour l'art" or "art for art's" sake:

"Modernism settled in painting with impressionism, and with that, art for art's sake. For which same sake the successors in Modernism of the impressionists were forced to forget about truth to nature. They were forced to look even more outrageously new: Cézanne, Gauguin, Seurat, van Gogh, and all the Modernist painters after them -- for the sake of aesthetic value, aesthetic quality, nothing else." (Greenberg, 1980, p. 6).

As opposed to Modernism that aimed at aesthetic universality and "unchanging criteria of quality" that are supposedly valid for all times and places, the contemporary art on the other hand aims at ephemerality. McEviley explains that modernist art though presented by beautiful objects lacked apparent content. He suggested that it implied that the society which produced such objects also lacked hidden agendas or contents "... after all the social situation producing such art was not pretty, then the art must bear a lie within, as Blake says the rose has a worm in it. Criticism, once enchanted by beauty of the rose, must now also attend to the worm." (McEvilley, 1992, p. 3)

The concept of postmodernism in the 1960's through pop art was more of playing with the mass culture imageries. It was a reaction to high modernism which catered only around the elite and their bourgeois culture. The postmodern artists on the other hand, were not detached from the society like the modernist artist, but rather were part of it. It was not until the arrival of critical postmodernism in the 1980s and 1990s however, that the artists turned to a more critical point of view of the commercialized world around them. The artists did not only engage with the images of mass cultural appeal like pop artists but these artists, "... acted as independent lenses onto the troubled world" (Koscianski, 2003, p. 81) and understood the hazards and dangers of a fast commercializing society where everything was saleable. Critical postmodernism is a nexus of both critical theory and postcoloniality , critical pedagogy and postmodern theory (Boje, 2001). According to Terry Smith, although the contemporary art has its origin firmly rooted in the critical postmodernism it has become an independent art movement almost as big as modernism itself (Smith, 2011, p. 77). Smith asserts that contemporaneity has come a long way in accepting artists as effective conceptual tools to comment and criticize the irritants in their respective societies with a flare of universal taste. Probably the most distinctive and most effective evolution in art was the eradication of the distinction between elite and mass culture with the arrival of pop art. This fact not only aided art in diversifying its audience but also encouraged the artists to deal with many significant subjects that would have been considered kitsch imageries a few decades back. The influence of critical postmodernism on contemporary art also came with an inherent cynicism, hopelessness and challenging as well as "rejection to all meta narratives" (Harrison, 2001, p. 12).

\section{Morbidity in Contemporary Art}

In many contemporary art approaches, the images of morbidity have become quite significant. There are many factors that have contributed in shaping contemporary art's fixation with morbid imagery, especially in the Third World. The disintegration of the Soviet Republic after the last phase of Cold War into several independent States sealed the fate for communism as an ideology in Eastern Europe. It also marked the beginning of New World Order and turned the United States into the sole super power in the world and consumer capitalism as an undesirable but only viable path. Along with it many incidents throughout the world shook humanity to its grounds like global warming, climatic changes that caused catastrophic tsunamis and earthquakes, man created disasters like the massacres in Rwanda, the bombing of the federal city in Oklahoma and the race for nuclear arms among nations (Robertson \& McDaniel, 2005, p. 11). But the biggest blow to the most positive post modernistic influence on contemporary art, that is globalization, came with the 
horrific incident of the September 11 suicide attacks upon the United States in New York City and Washington, D.C . The war on terrorism that followed the attacks in Afghanistan and later in Iraq, disrupted the postcolonial ideals of globalization based on equality of the "other." As Spivak explains, "The war is part of an alibi every imperialism has given itself, a civilizing mission carried to the extreme, as it always must be".(Spivak, 2004, p. 82) This is further supported by Akbar S. Ahmed, "Ideas and practice of multicultural harmony, eclecticism and juxtaposition which were at the heart of what commentators called postmodernism were halted in their tracks on September 11 2001."(Ahmed, 2004, p, i)

On September 11, no one could miss the symbolism of attack on the heart of the financial center of the western world. Nor could one miss the symbolism of the strike on the Pentagon, the heart of military might of America. But something has also been struck; postmodernism lay buried in the rubble on that fateful day (Ahmed, 2004, p. i).

It seems contemporary art was born out of despair. Postmodernism was failed once by science and its false promises but contemporaneity was failed twice. That gave it more bitter taste of morbidity than any form of art known before. Postcolonial writers like Homi Bhabha described the contemporary art situation as such:

"The 80's inaugurated a dream of difference which is now being haunted by horror and doubt: abhorrence of the 'deterritorialized flows' of global terror networks; doubts about feasibility of global politics with the increase in 'homeland' security and international surveillance; doubts about preemptive Strikes; doubts about war; doubts about our rights and responsibilities for the world and ourselves. What happened to the dream?" (Bhabha, 2003, p. 76)

If we look at the state of contemporary art, we could easily find works that are obsessed with mortality and despair - the kind of art that these contemporary artists made of human bodies, hair teased into patterns to form Chinese characters, or woven into rug, or plucked from the artist's body to be inserted into diminutive waxwork rendition of the corpse of the artist's father; blood let drip from self-inflected wounds onto canvas, or made into self-portraits; or mark making by ejaculating over drawings or even crucifixes and even a baby's corpse cooked and apparently eaten (Stallabrass, 2004, p. 1).

If we examine the works of contemporary artists we find the repetition of the same morbid themes over and over again with almost an obsession with the transience of human life .The most acclaimed work by Damien Hirst, "For The Love of God" (2007) (Figure 1) was made from a skull studded with diamonds. It is a simple remark over the mortality or ephemerality of life with modern consumerism's promise of eternity through the well-known advertisement tagline "Diamonds are forever." (Smith, 2009).The recent winner of Sharjah Biennale 2011, the site specific installation by Imran Quresshi , an important contemporary artist from Pakistan, titled "Blessing Upon the Land of My Love" (2011) (Figure 2) described a scene of suicide bombing in a mosque as witnessed by the artist. It is a classic example of the sublimity of the original trauma. Rizvi explains, "The installation depicts the bloody aftermath of bombing, its eerie quietness evoking a spine chilling scene. The viewer is compelled to re-enact the drama that has just taken place: a crowd of people is milling about, or praying in the courtyard of a mosque, when a suicide bomber strikes, leaving in his or her wake a ground soaked in blood." (Rizvi, 2011) Another example would be Rashid Rana's acclaimed digital photomontage "The Red Carpet" (2007) (Figure 3). Rashid Rana produces "'Red carpet' rugs that looked first like the familiar icons of Eastern craft and beauty revealed on a closer look the artist's own photographs of animal blood and gore in a Lahore slaughterhouse" (Lydon, 2011). The same theme also occurs in contemporary art works around the world; take another example of the conceptual art works from Araya Rasdjarmrearnsook an artist from Thailand, whose video installations captured the practice of volunteers reciting scriptures or poetry in morgues over the corpses of random strangers who did not get formal burial rights.

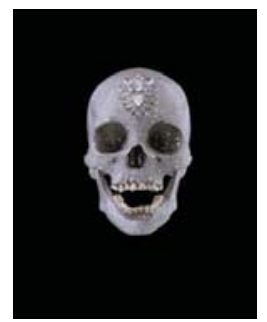

Figure 1. Damien Hirst, "For the Love of God" (2007), Platinum, diamond, human teeth.

Source: http://www.damienhirst.com/for-the-love-of-god 

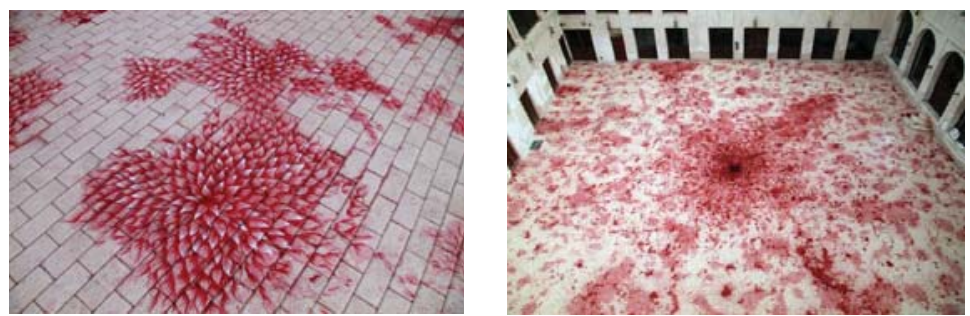

Figure 2. Imran Qureshi "Blessing Upon the Land of My Love" (2011), Acrylic and emulsion paint on interlocking brick pavement, site-specific installation, commissioned by Sharjah Art Foundation,

Source: http://www.sharjahart.org/projects/projects-by-date/2011/blessings-upon-the-land-of-my-love-qureshi

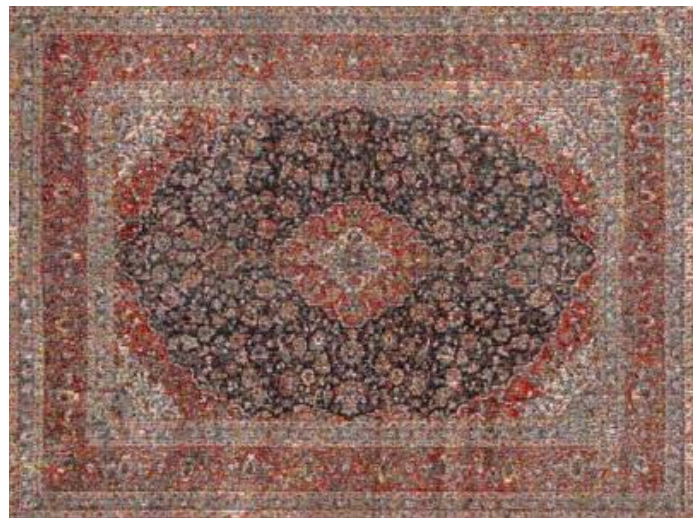

Figure 3. Rashid Rana, "The Red Carpet" (2007), Digital Print.

Source: http://artradarjournal.com/2010/08/05/rashid-rana-show-proof-of-musee-guimet-new-contemporary-acquisitionpolicy-interview-with-curators/

\section{The Mayan Myth}

In this atmosphere of a world obsessed with highly justifiable but extremely disturbing morbid and apocalyptic imaginaries, nothing could be more welcomed than the hype about the Maya myth predicting an apocalypse on the eve of $21^{\text {st }}$ December 2012 (21/12/2012). This myth has inspired a few books and some Hollywood flicks with an epic amount of box office success such as the film "2012" directed and co-written by Roland Emmerich. Maya is a civilization dating back to 500BC to $325 \mathrm{AD}$. According to some researchers, it was located to the north of Tabasco and South of Veracruz, present day Mexico. According to some loose interpretations of the cryptic calendar, the world was supposed to end on the eve the $21^{\text {st }}$ day of the $12^{\text {th }}$ month of the year 2012 .

\section{12: A Group Exhibition in Anticipation of the 2012 Apocalypse}

Though in Malaysian art, the imageries of morbidity are still quite limited in the artistic production of local artists, an interesting exhibition was organized in which the premise of such morbidity became the subject of interest among the participants. In anticipation to the forth coming apocalypse an art exhibition was organized in The Warehouse at 212, Beach Street in Georgetown, Penang. The participants were 12 artists both Malaysians and non-Malaysians. In the exhibition, each artist through his/her work contributed to what the end of the world meant to him/her. In this discussion, we will only examine the works of four artists who have participated in the exhibition that are aligned with the approach of morbid imageries, an over whelming trend among international contemporary artists. 


\section{Chee Eng Hong}

As one entreated the display area the first art piece that caught the eye was a series of five paintings/ installations by the artist, a media art enthusiast, Chee Eng Hong, entitled "Pang Sai Pun Boh Eng" (2012) (Figure 4). One of the works contained two identical paintings -- one monochromatic and the other in blue hues, with the monochromatic crouching figure overlapping the other work in blue hues. The monochromatic work depicted the posterior of a nude crouching male with cell phone in his hand fidgeting with the numbers on his phone. Under him was his excrement made from plastic cast bought from the souvenir shops around Kek Lok Si Temple. On the opposite wall, two paintings were displayed, one of a chicken and another one of a goat, which led the eyes towards a mirror on the floor in the middle. This mirror reflected the words written on the ceiling "AYAM", meaning "chicken" in Malay language, but when one read the words in the reflection it spelled "MAYA". The whole concept of the paintings was based solely on the local Chinese culture, illustrating a universal theme of modern day society's fixation with money. The nude crouching male was depicted entering from one year to another, obsessed with numbers (on his mobile phone) as a metaphor for wealth. According to the artist's own words "Pang Sai Pun Boh Eng" means "too busy to shit" while in Chinese culture human excrement is believed to bring good luck. The two paintings on the opposite wall were a clever twist of the words from Malay language and English pronunciation, ayam (chicken), kambing (goat) which was explained by the artist, that if one writes ayam backwards it spells "maya" and the pronunciation of "kambing" is more like "coming" in English language resulting in the sound of "Maya coming". So if we were to read this work it basically meant, that the man is too busy finding ways to make his fortune in the capital obsessed society, unaware that his luck actually lays under him and behind him is the apocalypse, which he is also unaware of.

Although very carefully thought out, the art work depended too much on explanatory baggage to be understood. It surely was a clever blend of regional or local imagery and a universal theme. It was classic attack on the shallowness of present times which has reduced human beings to money making obsessive men unaware of their surroundings and their blessings. It also pointed at the apocalypse that we are creating on earth that we are totally unaware of.
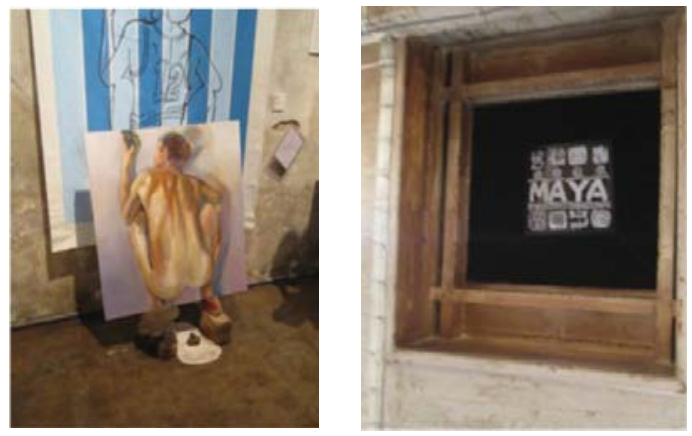

Figure 4. Chee Eng Hong, "Pang Sai Pun Boh Eng" (2012), Painting installation, mix medium.

\section{Low Chee Peng}

Self-taught and one of the most senior artists in the group was the seriously playful sculptor Low Chee Peng with his thought provoking installation series of three sculptures. The sculpture "Rest in Peace" (2012) (Figure 5) depicted a child with physical features that characterized many Asians, chiseled in white marble, lying inside a metal coffin with bronze bullets scattered around him. The metal coffin was raised from the ground by a mound of bricks. The infant carved out of white marble signified life and the bullets death. It was a brilliant commentary on the race of arms in nations on the pretext of saving lives but is actually used for destruction of human race, hence life and death at the same place. 


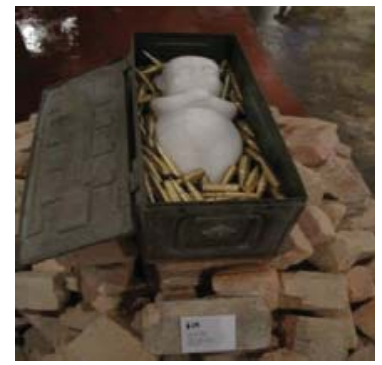

Figure 5. Low Chee Peng, "Rest in Peace" (2012), Sculpture installation, mix medium.

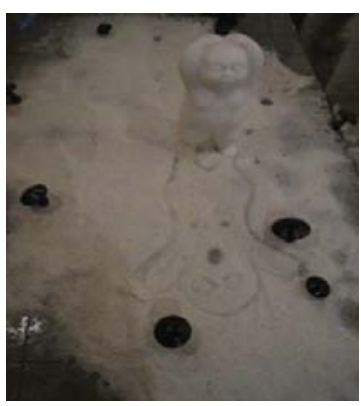

Figure 6. Low Chee Peng, "I Hate Mushrooms" (2012), Sculpture installation, mix medium.

There was a repetition of the infant carved in marble in Low Chee Peng's "I Hate Mushrooms" (2012) (Figure 6). It was a clever play of words to signify a hair raising phenomena of the nuclear arm race. The marbled infant held a black mushroom with white marble dust scattered around him. The shadow of the child was hand drawn on the marble dust forming the image of the famous art work titled "The Scream" (1893) by Edvard Munch. Many mushroom like growths proliferated around the standing marbled infant. The work infused two phenomena- the black mushroom clouds that are formed by nuclear bombs and children's inherent dislike for vegetables hence the "I Hate Mushroom". The repetition of the sculpture of a child, used as a metaphor for life also showed the artist's concern over the future of the human race being a father of a toddler himself.

The third and last installation titled "The Last tree" (2012) (Figure 7) consisted of the same imagery of a white marble sculpture of an infant placed inverted in between a barren tree trunk with all its leaves shredded to the ground. The sculpture/installation was a profound criticism on the global abuse and rape of the natural resources but by inserting the human form in between the tree trunk, the artist ingeniously unified environment and human life in the same bracket, interdependent on each other, implying that the death of the environment is the death of the human rac as well.

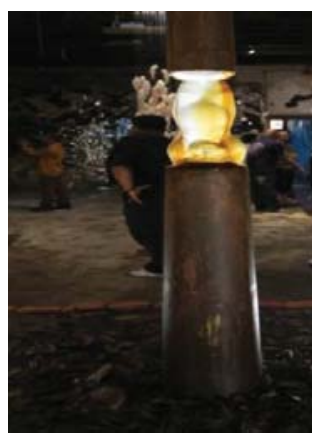

Figure 7. Low Chee Peng, "The Last Tree" (2012), Sculpture installation, mix medium 


\section{Louise Low}

There were two art works by the artist Louise Low, a site specific mosaic on the front wall of the 200 year old heritage building entitled "Are You Coming?" (2012) (Figure 8) and an installation sculpture on the right entitled "Coding Soon" (2012) (Figure 9). In her own words the glass mosaic on the wall signified the shattered world, the image of the Christ on the floor symbolized the first coming 20 centuries ago, which was mocked, full of spite and accused. Whereas the second image projected on the glass was resurrected and ruling. Although the site specific painting installation had a Christian theme based on the assumption that Christ would rise again on dooms day, there was an unconscious inherent disbelief in the title which is so becoming of our contemporary times -- "Are you coming?" -- the statement seemed more of an accusation rather than a question.

The second work by the artist commented on the theme of a society obsessed with consumerism. It consisted of 9 rectangular glasses about $6 \times 8$ inches installed on the wall and if one looked through it from a certain angle one would see a silhouette of a human figure superimposed by bar code commonly used for consumer products, hence the title "Coding Soon" ( Figure 9). As every saleable product has a code, this work suggests that it would also happen or has happened to humans as well as we lived in a world where everything is a saleable commodity, explained by Andreas Huyssen as "The invasion of capitalist technological instrumentality in the fabric of everyday life even the human body." (Huyssen, 1986, p. 11).

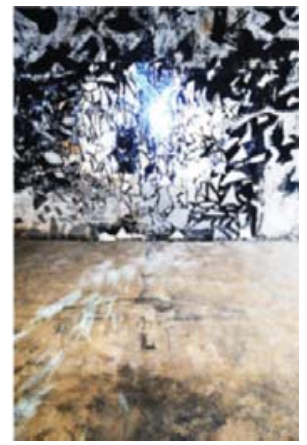

Figure 8. Louise Low, "Are You Coming?" (2012), Mosaics on the wall.

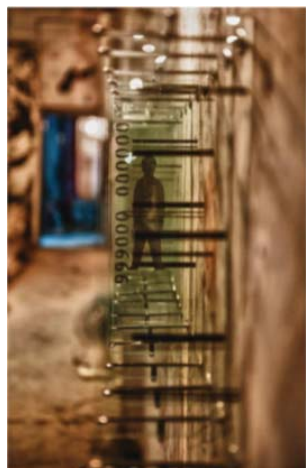

Figure 9. Louise Low, "Coding Soon" (2012), Stencils on glasses.

\section{Tan Kai Sheun}

An installation artwork by artist Tan Kai Sheun entitled "The Fragility of the Physical" (2012) (Figure 10) consisted of clusters of human figurines casted in resin suspended in a group from the ceiling. Although the posture of the figurine seemed like a person hanging himself, and the cluster of resin casted figurines seemed at first glance, a mass suicide 
scene, the artist denied such intentions. Under the installation of hanging figurines lay shattered pieces of broken glass from a cast. In the words of the artist himself, the use of the delicate and brittle material for the particular art peace was the prime concept behind the sculpture, as the reminder of the fragility of human life. Hence strong messages towards the futility of elaborate lifestyles and our obsession with materialism in the current society.

On the left, after the entrance door, there was another art work by the artist, a site specific painting in ink wash, entitled "Am I Not Invisible?" (2012) (Figure 11). A figure of a boy, painted on the wall with minimal use of color, rendering the painting almost transparent in nature, using the cracks and crevasses to create a three dimensional effect. The feet of the figure protruded out in shoes in a high relief. The image of the boy painted on the wall with a mischievous smile frozen on his face reminded the viewers of animal paintings from caves of Lascaux and Altamira. As if the boy was frozen in time, mummified, or fossilized by a sudden apocalypse. The torn down surface of the wall gave the figure a look of trauma or great agony as if someone was caught in a middle of a catastrophe at an awkward moment, unable to comprehend the situation. The transparency of the image invoked in the audience, the sense of isolation and invisibility that most of us experience in the present society obsessed with profits, where individual casualty is just a collateral damage.

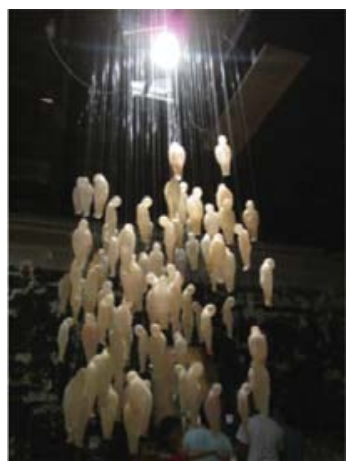

Figure 10. Tan Kai Sheun, "Fragility of Physical" (2012), Resin cast

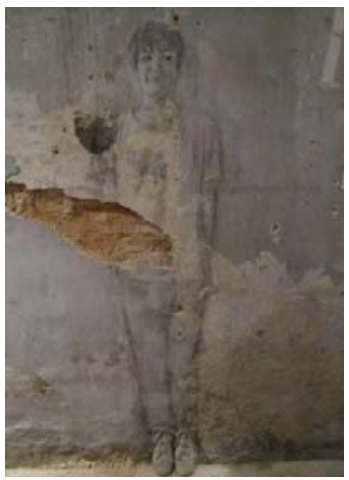

Figure 11. Tan Kai Sheun, "Am I Not Invisible?" (2012) ink wash, mix medium.

\section{Conclusion}

The venue of the exhibition, the general theme of the art works displayed and the atmosphere of the exhibition area, a crumbling-down warehouse declared as a heritage building, were in sync with the trend of displaying contemporary art in industrial places and warehouses as opposed to the white cube museum of modern art which promised immortality of art transcending the transience of life. The rain storm added rigor to the whole atmosphere superimposing the apocalyptic theme, with rain water leaking through the ceiling; loud music and free beers created an atmosphere of acceptance and 
total submission to the coming apocalypse, as if the images and art work around us were a kind of an account of our actions resulting in the punishment or retribution that was coming. As if the whole Apocalypse was just an extended expression or consequence of our acts displayed around us also known as "Nama-e-amal" in Arabic meaning the record of the deeds of an individual or a collective society according to which they will be judged in the afterlife. The arrival of the apocalypse just seemed a logical result of what humanity is doing to itself, raping of the natural resources resulting in violent climatic changes, wars, genocides, reduction of the human life to just a small piece of machinery in the current capitalist society. The Apocalypse almost seemed like a mutually curated or orchestrated event by humanity collectively, just like a self-inflicted bleeding wound of an artist in a performance.

One could not help but observe the recurrent theme in the artworks displayed, that is critique of the ruthless consumer capitalist society, where everything is for sale and profit is the sole intend. Every artist through an individualistic style of expression depicted through his or her art work how human beings have lost their individuality and visibility in the world to the obsession of accumulating wealth by the corporate world. Human existence seems to be of a minor value and the paramount concern in modern societies remains limited to generating money whether it is through the plunder of natural resources or manufacturing and marketing of lethal weaponry fueling wars and genocides in the world thus creating an inevitable apocalypse on earth. The audience could witness in the art works, the repeated images of isolation, misery, futility and fragility of life of ordinary individuals in the mechanical, capital fundamentalist world.

The exhibition made one speculate if the obsession with mortality of life is a response to the sudden absence of religious narratives in our modern money oriented societies. If the whole hype of the inevitability of death and universal extinction is humanity's effort of dealing with individual mortality in the absence of religious alternatives based on continuation of life after death through the concepts of heaven and hell. Extinction of an individual is always a death of a whole universe but the particular approach that humanity is in an inevitable apocalypse collectively makes it more bearable on an individual level and allow him/her to deal with the idea of his/her own mortality. Or has the mortality and transience of life become a valuable commodity for consumerism? If the media is capitalizing on the ephemerality and on life's transience, is art also a tool for the recent media's hype about selling temporality of life? Has art become another consumer friendly production and the obsession with mortality in contemporary art just a commercial hype, in sync with the same capitalist consumer society it criticizes? Selling what sells: nothing more nothing less. Is contemporaneity yet another hypocritical narrative in making, destined to rejection?

\section{References:}

Ahmed, A. S. (2004). Postmodernism and Islam: predicament and promise: Routledge.

Bhabha, H. K. (2003). Making Difference: The Legacy of the Culture Wars. ARTFORUM, 41(8), 73-73.

Boje, D. (2001). What is Critical Postmodern

Theory, from http://business.nmsu.edu/ d dboje/pages/what_is_critical_postmodern.htm

Greenberg, C. (1980). Modern and postmodern. Arts Magazine, 54(6), 64-66.

Grube, V. J. (2012). Drawn and Quartered: Reflections on Violence in Youth's Art Making. The Journal of Aesthetic Education, 46(2), 25-35.

Harrison, S. (2001). Pop Art and the Origins of Post-modernism: Cambridge University Press Cambridge.

Huyssen, A. (1986). After the great divide: Modernism, mass culture, postmodernism (Vol. 399): Indiana University Press.

Kee, J. (2011). Introduction Contemporary Southeast Asian Art. Third Text, 25(4), 371-381.

Koscianski, L. (2003). The emergence of critical postmodern art. Journal of Critical Postmodern Organization Science Vol, 2, 4.

Lydon, C. (2011). Rashid Rana's Pakistan: a mini-version of the globe, from http://www.globalconversation.org

McEvilley, T. (1992). Art \&Otherness:Cultural identity: Mcpherson\&Company.

Rizvi, N. (2011). Blood, sweat and tears, The Friday Times.

Robertson, J., \& McDaniel, C. (2005). Themes of contemporary art: Visual art after 1980: Oxford University Press.

Smith, T. (2009). What is contemporary art? : University of Chicago Press.

Smith, T. (2011). Contemporary Art: World Currents. Hong Kong: Laurence King Publishing.

Spivak, G. C. (2004). Terror: A speech after 9-11. boundary 2, 31(2), 81-111.

Stallabrass, J. (2004). Art incorporated: The story of contemporary art: Oxford University Press Oxford. 